\title{
CASTING: A METHOD OF ARCHAEOLOGICAL DATA RECORDING IN SAVING THE NATIONAL CULTURAL HERITAGE HISTORY VALUES
}

\author{
Casting: Suatu Teknik Perekaman Data Arkeologi dalam \\ Menyelamatkan Nilai Sejarah Warisan Budaya Bangsa
}

\author{
Lenrawati \\ Balai Arkeologi Provinsi Sulawesi Selatan \\ Jl. Pajjaiyang No. 13 Sudiang Raya Makassar, Indonesia \\ st.keppo@gmail.com
}

Received: 06/12/2020; revision: 28/08-08/11/2020; accepted: 09/11/2020

Published online: $30 / 11 / 2020$

\begin{abstract}
Abstrak
Casting sebutan lain dari penggandaan dalam dunia arkeologi. Casting diartikan sebagai upaya untuk merekam data yang ada pada suatu benda arkeologi secara akurat dalam bentuk tiga dimensi sehingga seluruh ukuran dan permukaan akan sama dengan benda aslinya. Pembuatan casting ini, dilakukan secara manual dengan melalui tiga tahapan. Tahapan pertama dilakukan pembuatan cetakan pola negatif, tahapan kedua dilakukan pembuatan cetakan positif, dan tahapan ketiga pendinginan serta pewarnaan. Berbicara mengenai casting, maka akan berfikir bagaimana teknik casting pada benda cagar budaya yang berukuran 0-7 cm dan berukuran kurang lebih 1 meter. Pembuatan casting bendabenda arkeologi bertujuan untuk kepentingan ilmu pengetahuan, tindakan penyelamatan, bahan pameran atau sebagai alat peraga pendidikan. Metode yang dilakukan di antaranya, pengumpulan data, pengelompokan data dan bereksperimen terhadap benda yang akan di casting. Pembuatan casting benda cagar budaya memiliki tahapan yang berbeda, tergantung tingkat kesulitan benda tersebut. Pembuatan casting termasuk upaya pendokumentasian dalam pekerjaan penyelamatan terhadap benda meskipun fisik bendanya sudah mulai rapuh atau rusak.
\end{abstract}

Kata Kunci: Casting, Dokumentasi, Arkeologi, Karet Silikon, Resin.

\begin{abstract}
Casting, a method of recreating an archaeological object, is intended to accurately record the existing data on that object from three-dimensional perspective. It allows the exactly same display as that of the original object. Generally speaking, casting consists of three manual stages: negative mold preparation, positive mold making and cooling and colorong. The current study focuses on objects measuring 0-7 $\mathrm{cm}$ and less than 1 meter. Making archaeological objects casting aims for the benefit of science, a heritage rescue, exhibition material or as educational aids. The methods employed in this research are data collection, data classification and actual experimenting on casting. The study indicates that casting has a wide range of processes, depending on the level of difficulty. Making casting is also an effort to recording in a work of saving objects even though the object has begun to become fragile or damaged. Keywords: Casting, Documentation, Archaeology. Sillicone Rubber, Resin.
\end{abstract}

\section{INTRODUCTION}

Casting or duplication in archeological sense means measures taken to record data available on an object accurately, using a three-dimensional shape in order to present it in the most exact similarity to its original one (Wijayanti, 2017, p. 1, 2018, p.
1). It is an act of pouring liquid material into a mold or mould, where it solidifies into a shape of the mold (Kriswandhono, 2018, p. 2). In addition, it is also a useful technique in integrating some pieces by covering the joints having been filled with wax-mixed 
clay. Following heating process, the cavity formerly containing wax is refilled with liquid metal as joining materials (Sukendar, 1999, p. 73). Casting consists of two phases: preparing the mold, generally known as negative mold; and positive mold or filling materials into the mold (Cahyandaru, 2013, pp. 105-109).

Experimental archeology is designed to bring back past events, relying on observations on a site, structure, tool or weapon. The obervations ultimately enlight the scientists on how the tools had been made (Rasyid, 2017, p. 129). Casting is not limited to artefacts; it, however, applies to photographs, images, and rare books, proving to be significant in interpreting past information for the development of science. Extracted data from casting upon an object are worthy documentation (Sarjiyanto, 2010, p. 61).

Post-casting process is crucially important. The documented information will be published so that the public gets to access it (Duli, 2014; Sutopo, 2016, pp. 1-2). Reviving archeological evidence in an object is to preserve the object itself (Brahmantara, 2016, p. 21).

Casting is applied to archeological excavations of historical significance, like human skeleton and burial goods, bone tools and other recovered remains (Wahyu, 2017, p. 3). It is allowed as long as it does not inflict any damage on the object (Wahyu, 2017, pp. 5-6). Following the above mentioned explanation, the question the current writer proposes is: "What kind of casting technique is suitable for $0-7 \mathrm{~cm}$ and less than $1 \mathrm{~m}$ object?" The real shape of an object is retained, and that of the cast can be put on display; the real objective, however, is for educational cause.

Casting is particularly of paramount importance for an archeologically rich complex like prehistory South Sulawesi (Duli, 2018; Duli \& Nur, 2016) and preIslam South Sulawesi (Rosmawati, 2008, 2011, 2013, 2017). The current study aims to describe four cast objects: stone artefact (oval axe), jar, shoe furnace and gravestone, having been through casting procedure.

\section{METHODS}

The first task this paper tackles is data collection, substantially needed in casting. Data were gathered through field visits (interviews) or note takings (library studies) from text books and related materials. Interviews were carried out by consulting with resource people. In addition, the writer was observing the whole process to get the vivid pictures of casting technology. Scaled pictures on the the writer's part are intended to visually record the whole lot.

Secondly, the data gathered were clustered. The clustering being through, the mold was then prepared. At the end of this second phase, a summary was issued.

\section{RESULTS AND DISCUSSION \\ 1. Casting Tools and Materials}

The tools needed in the experiment include a flat table, spatula table, $5 \mathrm{~mL}$ measuring cup, drop pipette, small, funnel, hand gloves, face mask, saw, $6 \mathrm{~mm}$ wood plank, rubber hammer, small scrap, sudip of bamboo, cutter, tiny brush, rubber fastener, mixing container, drill, sandpaper, bucket, toothpick and tea cloth.

As regards the materials, the casting relies on silicone rubber rhodorsil of type RTV 585 and its catalyst, silicone rubber rhodorsil RTV 586 and its catalyst, plasticine, vaseline, silicone oil, arindo resin, resin catalyst, talk (powder), plaster cast (plus gypsum), acetone, pigments (yellow, red, white, brown, black), rock powder, pilox clear, fiber (optional), gauze or its kind, and aluminium foil.

Rubber Rhodorsil (RTV) is a synthetic polymer with the most stable binding capacity (Figure 1), even in the temperature ranging between $100^{\circ} \mathrm{C}$ and $250^{\circ} \mathrm{C}$, not slightly vulnerable to sun exposure, temperature and humidity as well 


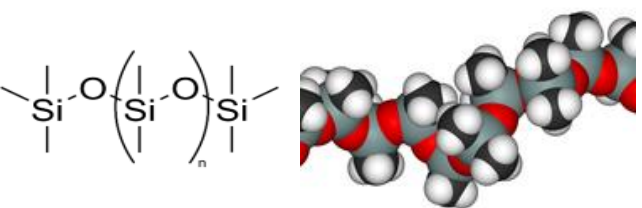

Figure 1. Polymer chain, 2D and 3D perspectives, of silicone rubber (Source: Wijayanti, 2017:12)

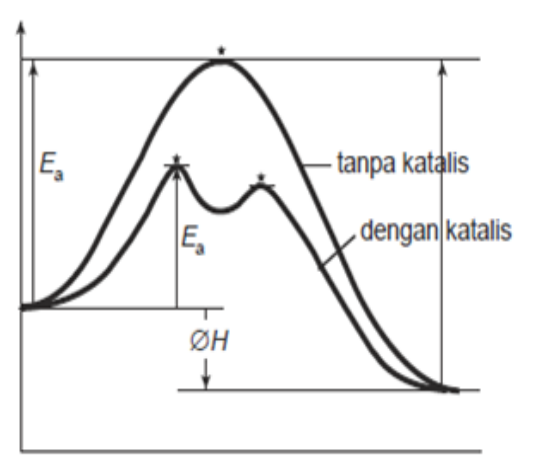

Figure 2. Energy Activation of Reaction versus Time (Source: Wijayanti, 2017).

as aging, chemical impact and oil. It is safe (food grade) and non-toxic and prevents microorganism growth, odorless, tasteless, prevents inherent color and corrosion or other impacts inflicted by contact with chemical materials. The only things left to be desired about it are its quite expansive pricing and the high demand for accurate mixing (Wijayanti, 2017, p. 12, 2018, p. 12).

Silicone rubber is highly sticky, in need of a catalyst to solidify it. A catalyst is a substance added to a chemical reaction to speed the process. It also reduces the activation energy (Figure 2). The latter is the amount generated in a molecule collision, serving to interrupt the original reaction by forming a new reaction (an intermediate) to give the final reaction product. Catalysts are not consumed in the catalyzed reaction but can act repeatedly (Wijayanti, 2017, pp. 1213).

As indicated in the figure, noncatalyzed reaction is shown with high curve, while the other one with two lower tops in the same span of time, the activation energy being lower in the catalyzed reaction. In general, a catalyst enables the drop in activation energy or speeds the reaction rate(Wijayanti, 2017, p. 13). Aside of silicone rubber, also added were arindo resin and resin catalyst, the latest being the factor in drying process (Agus, 2007, pp. 29-30).

\section{The making of negative and positive molds and coloring \\ a. Negative mold}

Prepare the heritage object (artefact) on the table, half the surface of which is covered with plasticine (wax), then applied with thin vaseline. A small fissure (groove) is made around $0.5 \mathrm{~cm}$ from the artefact, and so are $0.5 \mathrm{~cm}$ tiny holes as fasteners wrapped with vaseline. A $2-\mathrm{cm}$ peripheral border is built from the artefact's surface. One ounce of silicone rubber rhodorsil RTV 585 is mixed with 3.54 or $\mathrm{mL}$ catalyst, and is stirred gently and thoroughly. After that, pour the mix on top of the artefact; pin the bubbly mix with a toothpick to get rid of air deposition. Leave it until it gets dried; from there remove plasticine from the artefact. Prepare another mix to be attached to the side from which a mix has been previously removed. Once it is done, the negative is ready for use.

\section{b. Positive mold}

Vaseline is applied to the whole surface of the negative mold. Next, resin mix $(100 \mathrm{~mL})$ and talk (powder) and 3.5 or $4 \mathrm{~mL}$ catalyst are all stirred up and swiftly poured into the negative mold, not exceeding the silicone marker to get rid of unnecessary part taking shape (flipper-like part). The lateral aspect of the mold faces down and is fastened with rubber cut from tire, turned around in one direction to let it mix well. It being dried, cut off the the unnecessary part and clean it using aceton.

\section{c. Coloring}

The cast object is colored, starting from the most striking to the least striking color, applied and rubbed evenly and then polished with soft cloth and finally washed. Repeat the whole process when the attained color does not appear the same as that of the 
artefact. Once finished, spray some pilox to keep the color intact.

\section{The Casting on Cultural Heritage Objects}

Casting a cultural heritage object generally takes three steps: the preparation of negative mold; and that of the positive; and the cooling and coloring as the concluding part. The only difference is on the shape and size. This study is concerned with the casting of 4 tools: hand adze, jar, shoe furnace and gravestone. The reason behind those four is that they are different in both shape and size, meaning they will vary in production phases, with the following details.

\section{a. Artefact (Hand Adze)}

It takes two negative molds to produce an hand adze (figure 3 and 4). First, prepare the artefact and the base to which it is later placed, from plasticine. The plasticine covers half of the stone without any hole to prevent unnecessary part from forming. Make a peripheral groove as the fasterner and so is a peripheral border to secure the mix when the casting starts. Apply vaselin and plasticine to the whole surface. Mix silicon rubber and catalyst with

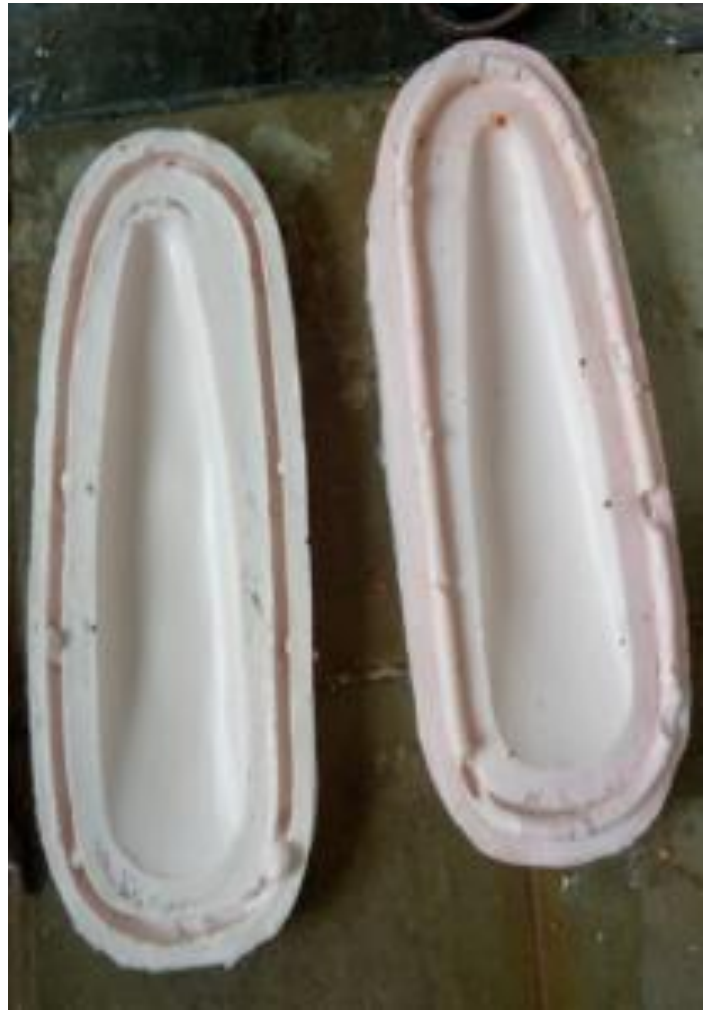

Figure 3. The Negative Mold of Oval Axe

(Source: Lenrawati, 2018)

the proportion of $100 \mathrm{~mL}+3.5 \mathrm{~mL}$. Stir it well and pour it into the stone artefact and wait until it gets solidified. After that, remove the plasticine and clean the stone. Next, make another peripheral border on the

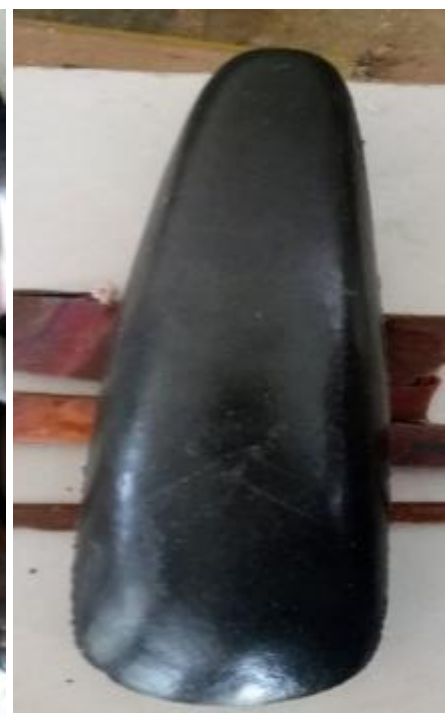

Figure 4. Left side is positive mold indicating joint; the right is superior view or the surface of the oval axe (Source: Lenrawati, 2018) 
stone. Vaseline and plasticine are applied to the stone and later silicon rubber mix on it and let be until it is getting solidified. When the second part is due, take out the stone.

To make a positive mold, prepare a $100 \mathrm{~mL}$ resin, rock powder plus 3.5 or $4 \mathrm{~mL}$ resin catalyst; all are stirred up well to come up with a good mix. The mix is then poured into the negative mold. The one is fully filled at once while the other is slowly poured with mix. When the mix gets a little solid in texture, face the two molds each other, shake them so they merge perfectly. Let them be until fully getting dried. Open the mold but avoid touching the positive mold due to it still being hot as not to leave any hole on it. When it is cool, clean the duplicate object from any flaw using a knife, cutter, or sandpaper and acetone and soft cloth. It is later covered with rock powder and wiped to the whole surface to make it resemble the real one.

\section{b. Jar}

As regards jar, it takes three pieces of negative mold to come up with a positive mold (Figure 5, 6 and 7). All materials being ready, the first and foremost step is to prepare a footing on the wood plank. Prepare

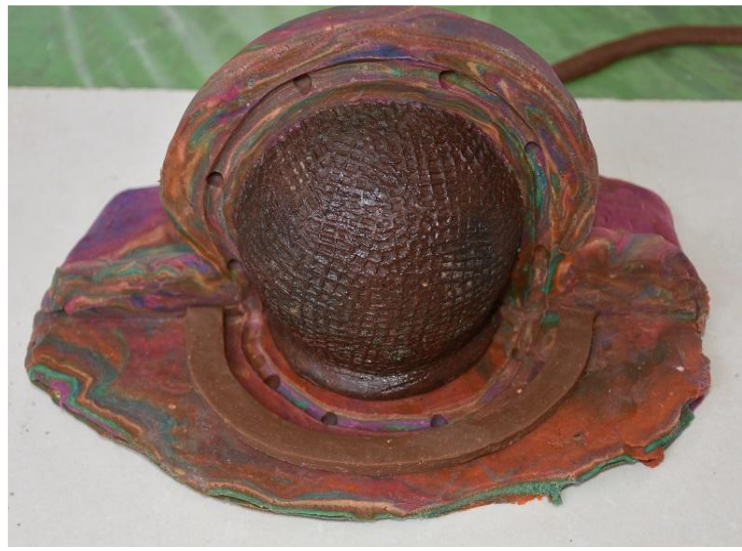

Figure 5. Jar on a footing, with divided areas from plasticine (Source: Lenrawati, 2018).

some plasticine on the footing then put the jar on it; then apply vaselin to it using bursh.

Prepare a border on the jar, at the exact half. Then add small groove with some holes as fasteners. Then indicate a separation near the groove. Mix silicon rubber of 100 $\mathrm{mL}$ with a catalyst of $3.5 \mathrm{~mL}$ (in case 200 $\mathrm{mL}$ of silicone rubber, then the catalyst should be two times that of the normal, $7 \mathrm{~mL}$ ). After that, apply the mix to the jar evenly to generate the first part of the mold. Cut of some gauze and attach it to the silicon rubber. It strengthening the mix, press the gauze to the mix using brush for it to better
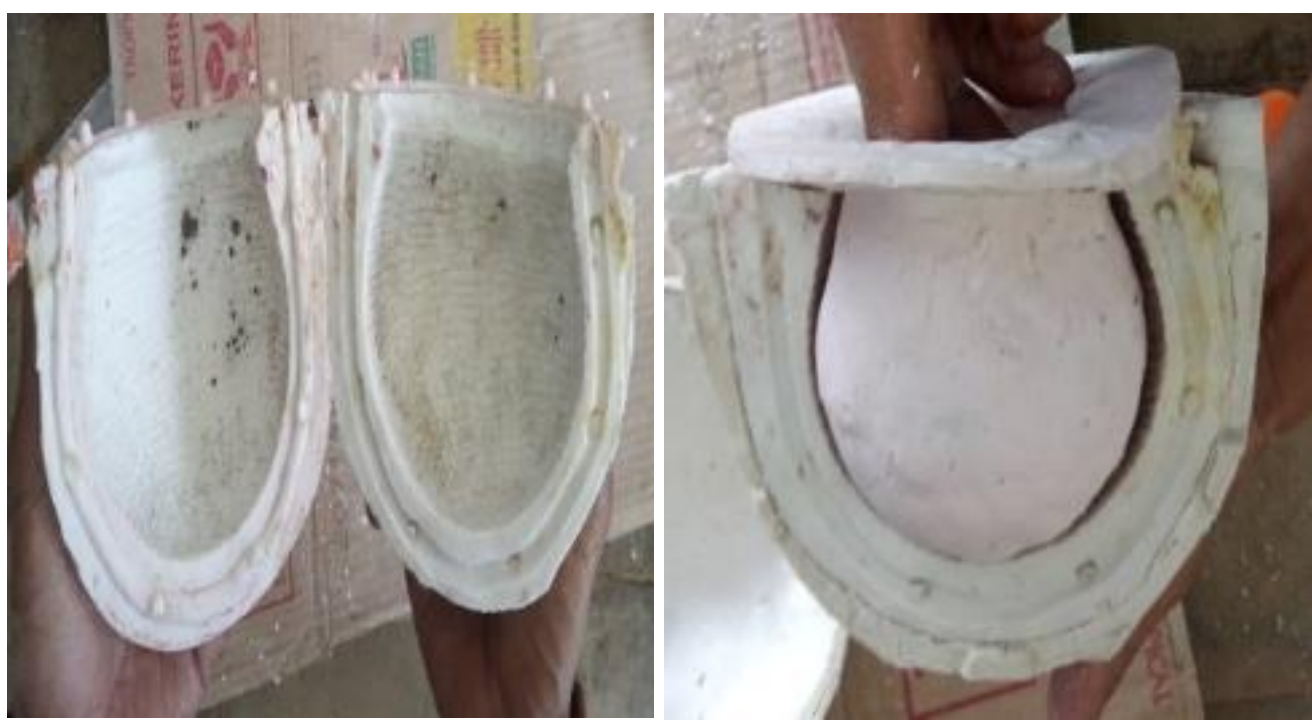

Figure 6. The three sides of the negative molds of the jar (Source: Lenrawati, 2018) 


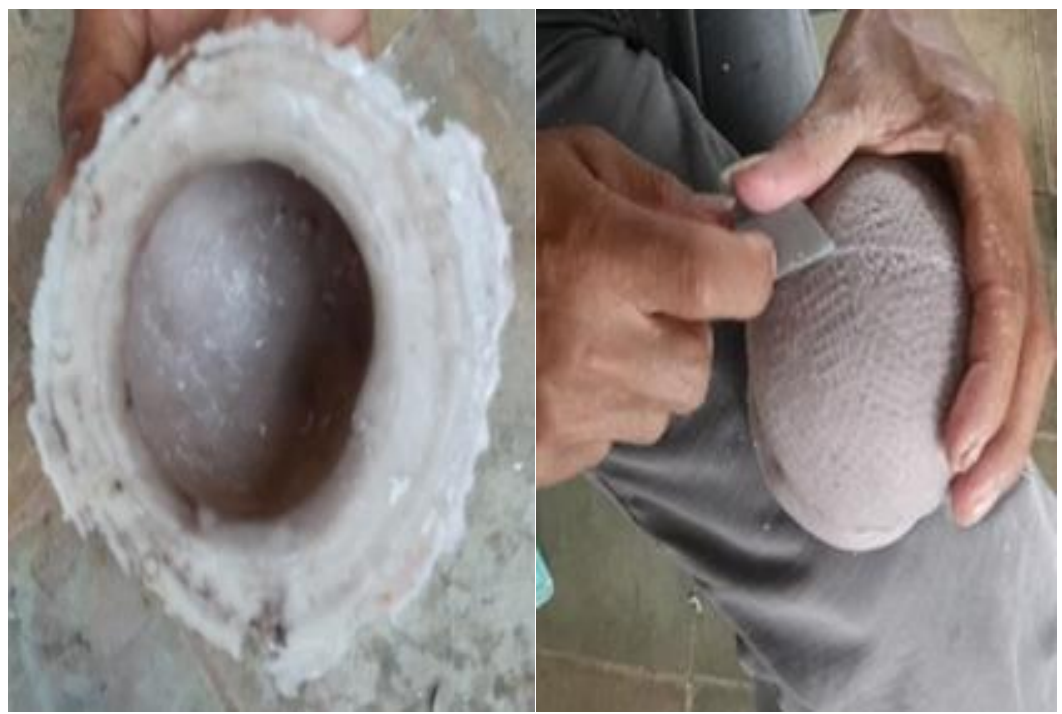

Figure 7. On the left is the flipper-like part of the mold and the rigt one is the method taken to remove it

(Source: Lenrawati, 2018)

stick to it. Another mix is added on to cover the attached gauze to further upgrage the strength of the negative mold. Remove all those added layers. When done, prepare another footing and a partition to support the gypsum, the latter being the pillar to prevent the negative mold from sudden move. Gypsum sizing depends on the scale of the container to secure. Put the gypsum into the water and make sure it is not extremely dissolved so as to prevent it from melting.

When the mix is ready, pour the gypsum into the mold until it covers the whole lot, and let it be dried perfectly. Remove the plasticine layer (divider) when the allocated time is due. That being through, mold for the second part is prepared, following all the stages previously conducted. With the two molds now done, footing for flipping purpose is readied. The jars face upward to let the inside part discernable. The inside part is cleaned, and applied with vaselin down to the mouth of the mold, as a step to move on to the third mold. After that, a border (divider) from gypsum is established to keep silicon rubber from crossing the other side. The latest procedure differs slightly from the former two since silicon oil is added to the mix, giving it flexibility; the dose is estimated based on the desired rubber's flexibility, supplemented with $3.5 \mathrm{~mL}$ catalyst. The mix is poured wholly to the mold until the best texture is gained. Facial tissue is inserted into the mold as fastener before plasticine is applied to really make sure it is well-pressed. Once the rubber is dried, the plasticine layer is then removed and covered with new layer of plasticine before anointed with vaselin. The gypsum mix is poured into the rubbertissue and left to dry. When the structure is dried, remove the plasticine layer and polish the whole surface. And the negative mold is now ready to use.

The three negative molds are opened and the contained jars are taken out. The mix of positive mold is prepared and is added with proper dye as not to damage the inherent nature. Once the negative mold's surface is fully covered, prepare another layer of mix, with the same procedure as the one before. Once declared sufficiently dried, the casting mold is shaken so the mix inside is distributed evenly. Leave it for 5 minutes, and take the positive mold (duplicate) out. It being cool and completely solid, remove the unnecessary parts; to really look like the original, and add dye to the cast object. 


\section{c. Shoe Furnace}

It takes two negative molds to create a positive one. The negative mold is placed on a table having been footed with plasticine.

To begin with, shoe furnace is partitioned on the upper part and the lower part; the latter is prepared as the aperture for casting purpose (Figure 8 and 9). After that, it is covered with silicon rubber and later with vaselin. Also attached to the whole surface of the furnace is gauze. Another layer of rubber is added on top. Once fully solidified, the rubber is removed and is polished. Vaselin is applied to both upper (head) and lower (feet) parts. Mildly drying rubber is covered with gauze with gentle pressure and recovered with silicon rubber. The rubber on the upper is cleaned and given vaselin before being augmented with gypsum on three upper side covered with aluminium foil. Gypsum being wrapped by aluminium foil, make another layer (barrier) of plasticine on the rim or mouth of the furnace and add another layer. At the end, rub vaselin to the whole silicone rubber and aluminium foil including plasticine layer.

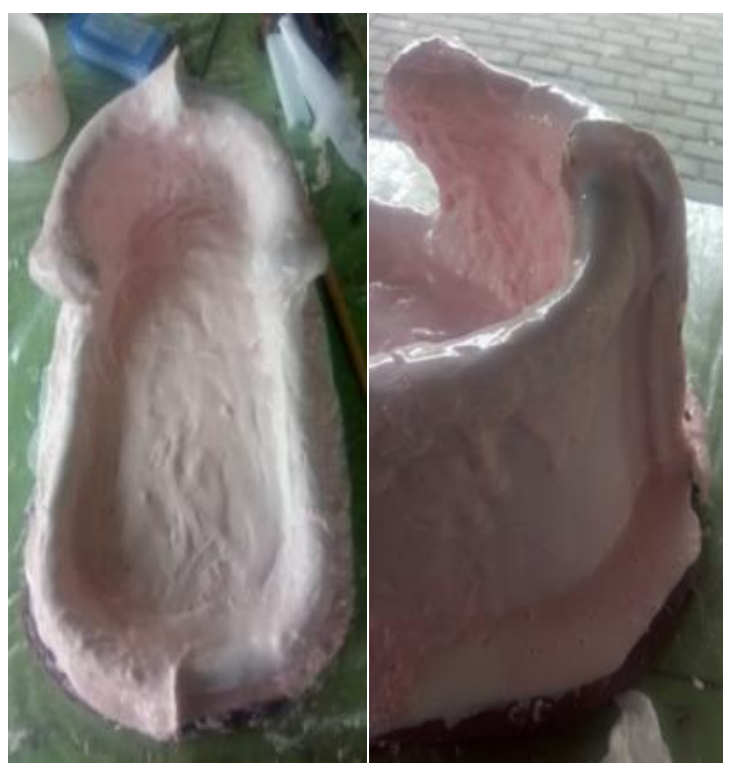

Figure 8. The making of negative mold; the fastened mold on the right (Source: Lenrawati, 2018).

Prepare a mix of resin powder and catalyst to create a layer covering silicon rubber on the negative mold. The allocated time being due, coat it with fiber. Add another layer of resin mix without having any space left. When the fiber layar gets dried, remove the plasticine and put aluminium foil on it. Again, put on some
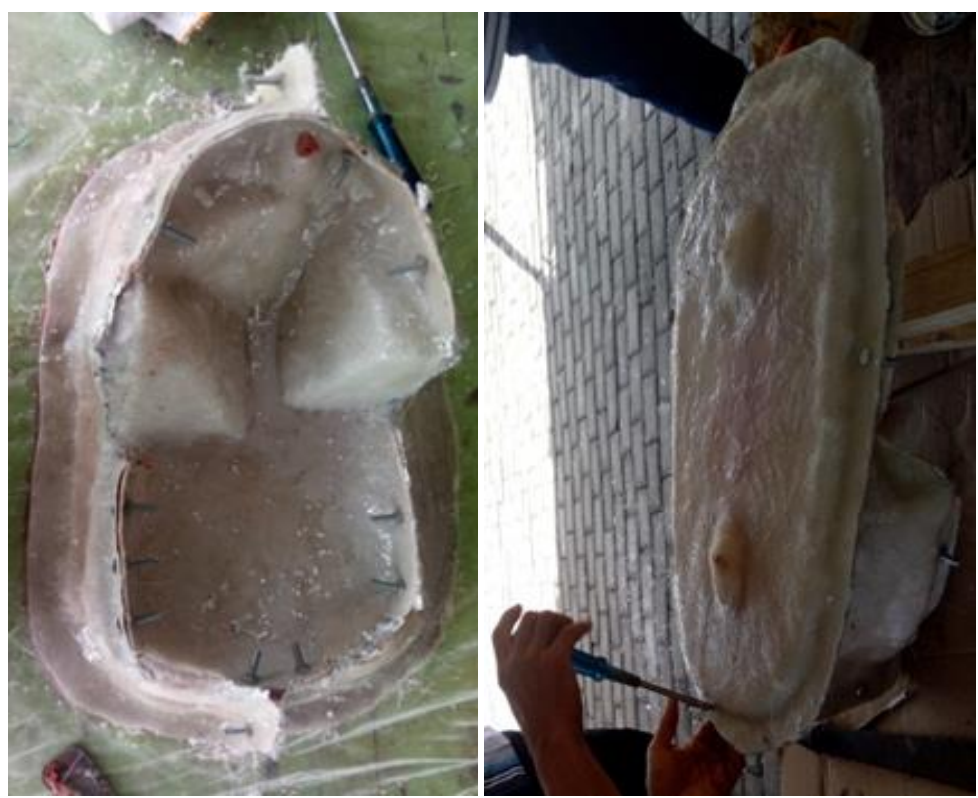

Figure 9. Images indicating negative mold made of resin and fiber augmented with bolts (Source: Lenrawati, 2018). 

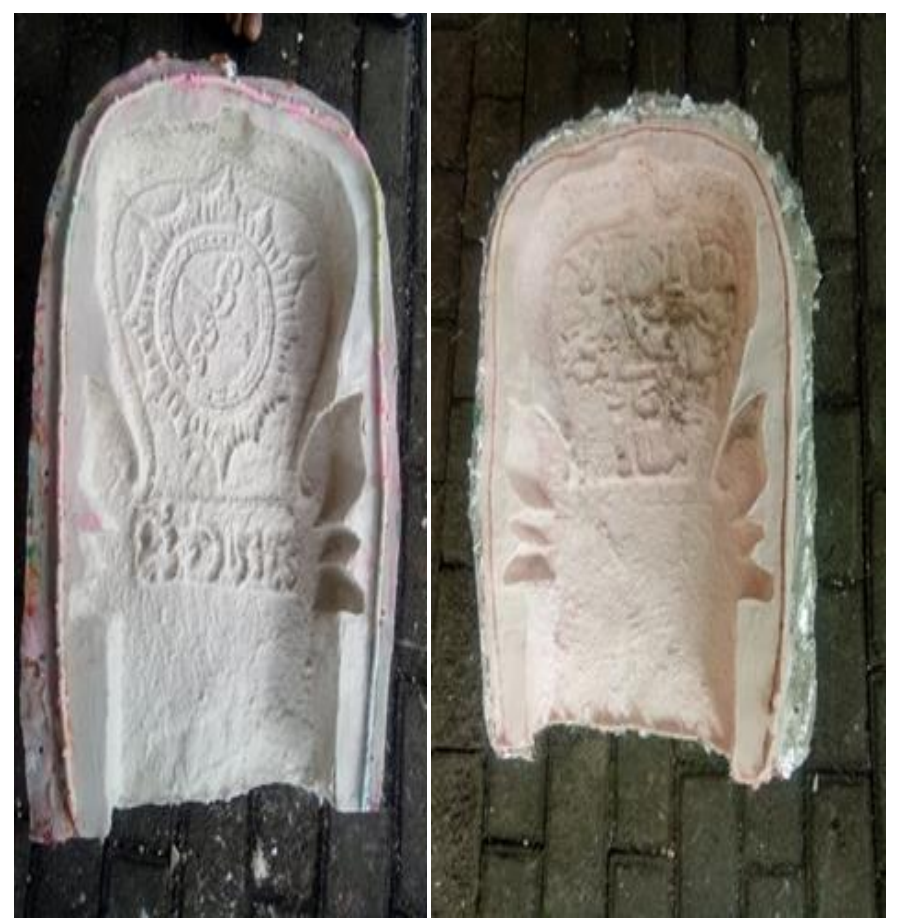

Figure 10. The two sides of negative molds for gravestone casting (Source: Lenrawati, 2018).

vaseline and the mix of resin, powder and catalyst. When it has reached the desired texture, correct it from all the flaws and fasten it with bolts. All those steps done, flip it to move on to the second part of the negative mold. Remove the plasticine where the furnace stands, put plasticine on the fiber, vaseline and another layer of rubber and then two cotton balls covered with silicon rubber as fastening mechanism. Remove plasticine on the fibered surface and put on aluminium foil, vaseline and resin mix. After that, place another layer of resin on it, to be bolted later. On the other hand, a mix of resin is also prepared, for positive mold. Pour the mix into the negative mold, to be stirred to have a well-blended mix, and let it reach the desired texture.

\section{d. Gravestone}

As does the previous one, it takes two negative molds to have a positive mold to produce a cast gravestone (Figure 10, 11 and 12). The first part of the negative mold is prepared and is given a barrier from plasticine. Apply vaselin to the whole surface. Set up a mix of silicone rubber and catalyst $(100 \mathrm{~mL}+3.5 \mathrm{~mL})$, and put it on the surface. Place some gauze on the silicone, and is pressed down using brush. The cavity found on the structure is filled with mix containing rubber so as to prevent it from tearing when removed from the mold. Add some mix of cotton balls containing silicon rubber on the gravestone surface when it is fully flat. Place a mix of plasticine on that latest layer. Put some vaselin to the whole surface. Make a mix of powder content and resin of $500-600 \mathrm{~mL}$, with $3-4 \mathrm{~mL}$ of catalyst; put the mix on the latest-layered surface. The pieces of fiber are attached to cover the whole mix. Prepare another line of $\operatorname{mix}(100 \mathrm{~mL}+4 \mathrm{~mL})$, and place it on the fiber while pressing it gently to allow no cavity. When the fiber layer dries, remove the plasticine; the former is layered with aluminium foil to provide for easy opening in casting. Once the fiber layer dries, bolts are added; the process then resumes to the second part of the negative mold.

To get a positive mold, it takes a mix of resin, resin catalyst and powder. It also 


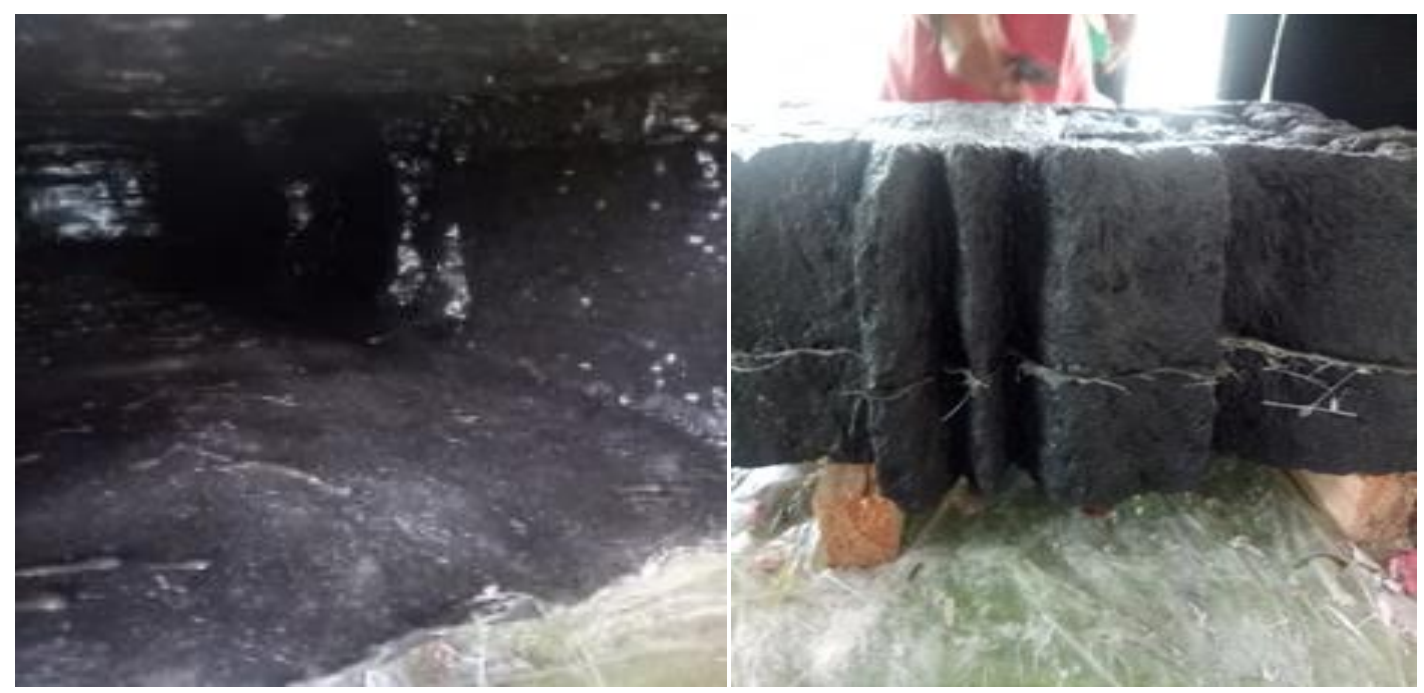

Figure 11. On the left is resin mix placing on the positive molds joint; unnecessary parts from the joining process (Source: Lenrawati, 2018).

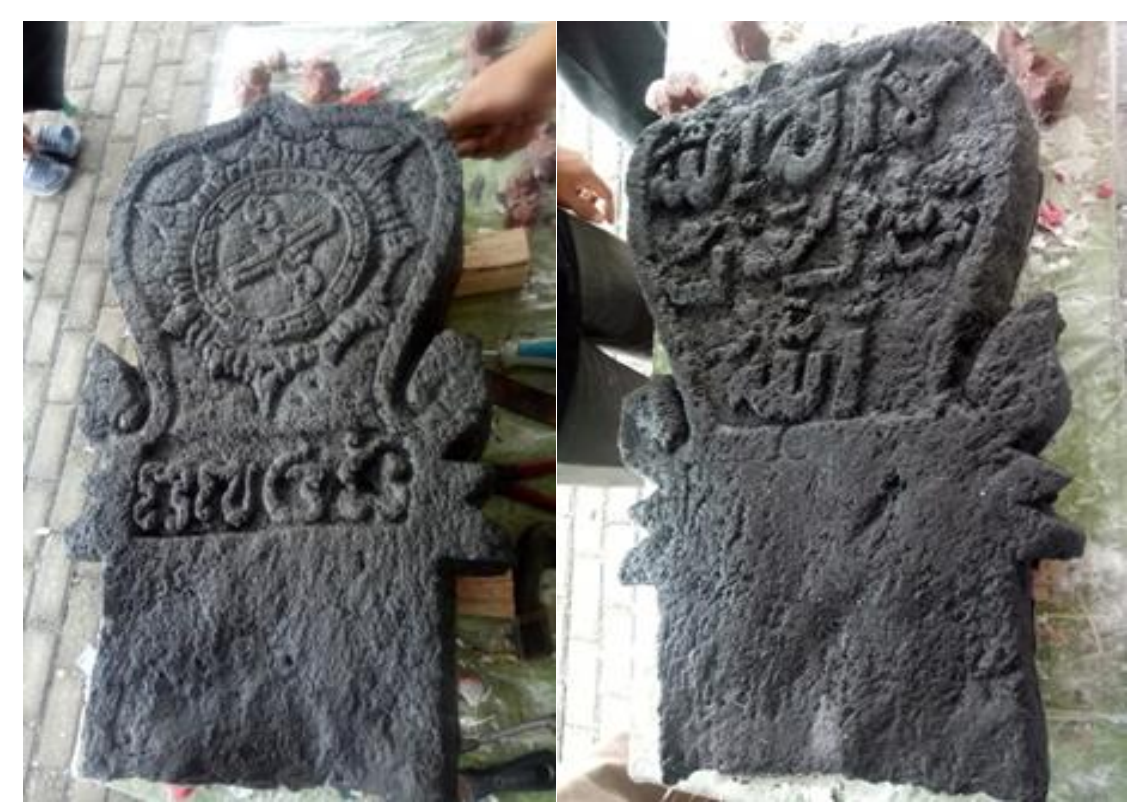

Figure 12. The cast gravestone (Source: Lenrawati, 2018).

needs dye so the basic color of the rock stands out, fiber and refining touch.

\section{CONCLUSION}

Casting cultural heritage objects takes different approaches, depending on the shapes. Take for instance, artefacts which presents hard time due to its almost square shape, as does a gravestone requiring supports, owing to its big enough size. Jars, on the other hand, are more challenging in the process of making; they should keep rotating to get rid of possible cavity while pouring the resin mix into the mold. Moreover, the body parts should be tied to keep them together and to banish the unnecessary parts. It takes fiber supports to ensure perfect pouring when casting a shoe furnace. In a nutshell, casting is by all means part of the efforts to preserve cultural heritage. 
Speaking of cultural heritage objects, in particular those observed in this study, the materials needed include silicon rubber and its catalyst, resin and its catalyst and also some vaselin; the later is especially vital in easy removal of the cast objects from the mold. Another equally important point to have in mind is to make sure the fastening mechanism does not wash away the crucial information available on the objects' surface.

Casting has evident edge in making elaborate and big structure (object); however it has some downfalls like low quality of surface texture and the possibly irresponsible act of forgery.

\section{ACKNOWLEDGEMENT}

The writer would like to express massive gratitude to Puslit Arkenas to have allowed me to join some workshops. The same gratitude is due to Ginarto, and Slamet for the valuable assistance in casting drills. The writer also thanks Aryani (Balai Arkeologi D.I Yogyakarta) and Eni (Pusat Penelitian Arkeologi) to have enlightened me about chemical reactions in casting.

$* * * * * * * *$

\section{REFERENCES}

Agus, I. H. (2007). Komposit Berpenguat Serbuk Tempurung Kelapa Sawit Dengan Resin Arindo Butek 3210 Sebagai Alternatif Pengganti Kampas Rem. Universitas Sanata Dharma.

Brahmantara. (2016). Perkembangan Sistem Pendokumentasian Cagar budaya Dengan Teknologi Terestrial Laser Scanner 3D. In Merekam jejak masa lalu cagar budaya dalam perspektif 3 D. Magelang: Balai Konservasi Borobudur.

Cahyandaru, N. (2013). Pengantar Konservasi Cagar Budaya Logam. In Modul Pelatihan Tenaga Teknis Konservasi Tingkat Menengah. Magelang: Balai Konservasi Borobudur.

Duli, A. (2014). Pemanfaatan Cagar Budaya. Buletin Somba Opu, 17(2), 1-9.

Duli, A. (2018). Sistem Penguburan Akhir Jaman Prasejarah di Sulawesi Selatan. ELS-JISH.

Duli, A., \& Nur, M. (2016). Prasejarah Sulawesi. Makassar: FIB Press.

Kriswandhono, A. (2018). Casting (Penuangan dan pengecoran). Bahan Presentasi Workshop Casting Tahap II, Punung. Punung.

Rasyid, A. (2017). Teknik Pembuatan Serpih Bilah Dengan Pendekatan Arkeologi Eksperimental. Walennae: Jurnal Arkeologi Sulawesi Selatan dan Tenggara, 15(2), 127144. https://doi.org/10.24832/wln.v15i2.273

Rosmawati. (2008). Pemaknaan Inskripsi Pada Makam Kuno Katangka di Kabupaten Gowa. Universitas Hasanuddin.

Rosmawati. (2011). Tipologi dan Perkembangan Bentuk Jirat dan Nisan Makam Kuno di Sulawesi Selatan. Jurnal Lensa Budaya, 5(3).

Rosmawati. (2013). Perkembangan Tamaddun Islam di Sulawesi Selatan, Indonesia: Perspektif Arkeologi dan Sejarah. University Sains Malaysia.

Rosmawati. (2017). The Manifestation of Malay and Local Cultural Acculturation at The 
Baginning of Islamization at Luwu, Case Study at Lokko'e Tomb Complex, Palopo. Asian Journal of Social Sciences \& Humanities, 6(2).

Sarjiyanto. (2010). Pembentukan Museum Arkeologi Indonesia (Universitas Indonesia). Retrieved from http://lontar.ui.ac.id/file?file=digital/20251403-RB00S38p-Pembentukan museum.pdf

Sukendar, H. (1999). Metode Penelitian Arkeologi. Jakarta: Pusat Penelitian Arkeologi Nasional.

Sutopo, M. (2016). Pendokumentasian Cagar Budaya. In Merekam jejak masa lalu cagar budaya dalam perspektif 3 D. Magelang: Balai Konservasi Borobudur.

Wahyu, E. S. (2017). Materi Workshop Casting Tahap 1. Punung. Jawa Timur.

Wijayanti, A. (2017). Laporan Workshop casting tahap I. Jakarta: Pusat Penelitian Arkeologi Nasional.

Wijayanti, A. (2018). Laporan workshop casting tahap II. Jakarta: Pusat Penelitian Arkeologi Nasional. 
Appendix 1. Photo of casting activities for the discovery of human skeletons at the Leang Jarie Site (Source: Balai Arkeologi Provinsi Sulawesi Selatan, 2019)

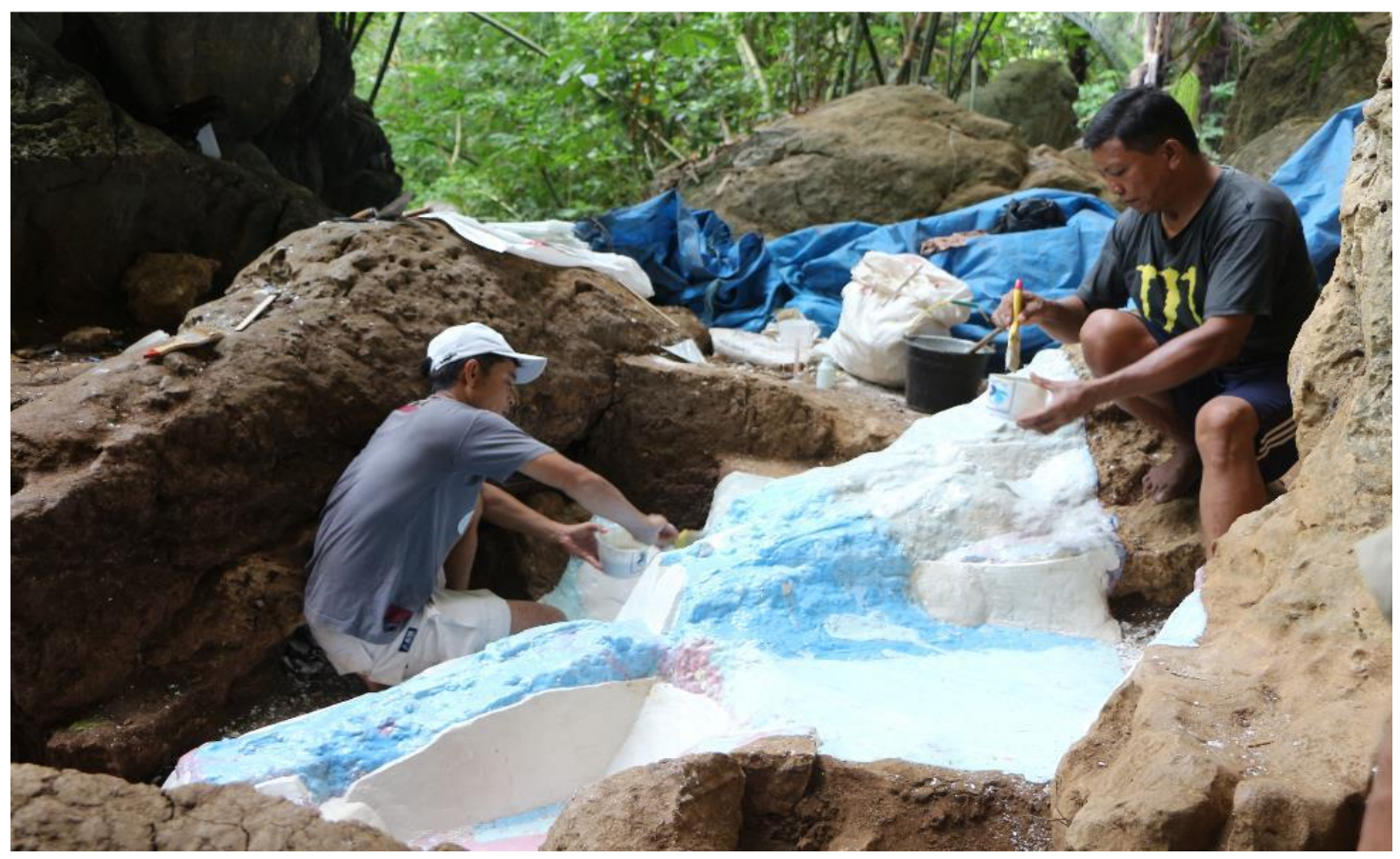

